\title{
Conversion of Cropland to Grassland and Forest Mitigates Global Warming Potential in Northeast China
}

\author{
Shujie Miao', Yunfa Qiao ${ }^{1 *}$, Futao Zhang ${ }^{2}$ \\ 'Nanjing University of Information Science \& Technology, Nanjing 210044, China \\ ${ }^{2}$ University of Chinese Academy of Sciences, Beijing 100000, China
}

Received: 14 November 2014

Accepted: 29 December 2014

\begin{abstract}
In converting cropland to grassland and forest, more carbon is sequestered in grassland soil and forest biomass, but the mitigation of global warming potential (GWP) is not clear. In this study, we use the longterm conversion from cropland to grassland (28 y) and forest (14 y) to comprehensively assess the impact on GWP of soil carbon $(\mathrm{C})$, nitrogen $(\mathrm{N}), \mathrm{CO}_{2}$, and $\mathrm{N}_{2} \mathrm{O}$ emissions. The results showed that compared to the original cropland, conversion to grassland increased soil $\mathrm{C}$ content by $51.1 \%$, soil $\mathrm{N}$ content by $28.4 \%$, soil C stock (SCS) by four times, $\mathrm{CO}_{2}$ emission by $17 \%$, and $\mathrm{N}_{2} \mathrm{O}$ emission by $40 \%$; soil $\mathrm{N}$ stock (SNS) decreased by half. The corresponding values after afforestation were $7.2 \%, 5.2 \%$, three times, $3 \%,-80 \%$, and half, respectively. Overall GWP in the cropland system was calculated using the fuel used for farming production, the change in soil $\mathrm{C}$, and $\mathrm{N}_{2} \mathrm{O}$ emissions. Due to large $\mathrm{C}$ sequestration, the GWP of conversion to grassland $\left(-1667 \mathrm{~kg} \mathrm{CO}_{2}-\mathrm{C}\right.$ equivalent ha- $\left.{ }^{-1} \cdot \mathrm{y}^{-1}\right)$ and forest $\left(-324 \mathrm{~kg} \mathrm{CO}_{2}-\mathrm{C}\right.$ equivalent ha' $\left.{ }^{-1} \cdot \mathrm{y}^{-1}\right)$ were significantly lower than the cropland system ( $755 \mathrm{~kg} \mathrm{CO}_{2}-\mathrm{C}$ equivalent ha- $\left.{ }^{-1} \cdot \mathrm{y}^{-1}\right)$. The relationship between GWP and greenhouse gas, between GWP and the change of total $\mathrm{C}$ and N, suggest that in rain-fed agricultural systems in northeast China, the conversion from cropland to grassland and forest can mitigate GWP through changing $\mathrm{CO}_{2}$ and $\mathrm{N}_{2} \mathrm{O}$ emissions.
\end{abstract}

Keywords: land use change, $\mathrm{CO}_{2}$ and $\mathrm{N}_{2} \mathrm{O}$ emissions, change in soil carbon stock (SCS), global warming potential (GWP)

\section{Introduction}

Global warming is now recognized as a major threat to natural and socio-economic systems with rapid population growth and economic development around the world $[1,2]$. Increasing anthropogenic contributions to atmospheric greenhouse gas concentrations [3] and changes in soil carbon and nitrogen stocks [4] are critical sources for global warming. Afforestation and establishment of grasslands on previously cropped sites are considered to be effective and

*e-mail: qiaoyunfa@163.com cost-efficient mitigative response strategies to climate change because of the ability of forest and grassland sites to sequester $\mathrm{CO}_{2}$ from the atmosphere and store more $\mathrm{C}$ and $\mathrm{N}[5,6]$.

It is well documented that land use change affects soil carbon stocks (SCS) [7-11] and greenhouse gas (GHG) emissions [2, 12-14]. However, with the population growing and diets changing in developing countries, more land is required for agriculture to meet food demands $[15,16]$. Changing grassland to cropland systems in temperate regions has resulted in losses of soil organic $\mathrm{C}$ (SOC) from $18 \%$ to $29 \%$. By 2010 , land use change was responsible for 
about $30 \%$ of the increase in atmospheric $\mathrm{CO}_{2}$ [2], $7 \%$ of the increase in $\mathrm{N}_{2} \mathrm{O}$ [13], and less than $1 \%$ of the increase in $\mathrm{CH}_{4}$ emissions $[17,18]$. Converting farmland to grassland or forest becomes a valid and potentially useful means for SOC restoration and GHG mitigation.

When farmland is abandoned, SOC stocks can significantly increase after conversion to pasture $(19 \%)$ and tree plantations (18\%) [10]. These increases depend on the amount of rainfall [8], clay content of soil, and vegetation species [19]. Following such transitions, there is an increase in organic matter inputs to the soil and reduced atmospheric $\mathrm{CO}_{2}$ concentration because of the ability to sequester $\mathrm{C}$ in vegetation and soil [20]. In the soil, microclimatic conditions such as microbial community, moisture, and temperature will be modified by the transition. Small changes in the SOC pool could have dramatic impacts on atmospheric $\mathrm{CO}_{2}$. The response of SOC to global warming is of critical importance [15].

Accounting for GHG emissions and global warming potential (GWP) of cropping systems requires evaluating their net impact on all emissions associated directly and indirectly with crop production [21]. GHG emissions are associated with agricultural inputs (machinery, seed, fertilizer, and agrochemical production) and diesel fuel used in farm operations [21]. Insect damage also removes $C$ from the ecosystem. With global warming recognized as a major threat to natural and socio-economic systems, China recently launched the 'Grain-for-Green' Program, stimulating the conversion of cropland to forest and grassland [10]. The average increase in SOC stocks was 26\% after cropland conversion to forest [8]. Restoration of cropland back to grassland systems may restore $7-18 \%$ of native $\mathrm{C}$ stocks over a 20 -year period in temperate moist and dry climates [22, 23]. However, Laganiere et al. [19] in a review of 33 recent publications, showed that afforestation has had mixed results, leading to decreases, increases, and negligible effects on SOC stocks. Of these references, only Wang et al. [24] identified former arable soils as a sink for $\mathrm{CO}_{2}$ after conversion to forest in the temperate continental monsoon climate of northeast China. In China, the largest grain producing area is located in the northeast. It is therefore imperative to understand the extent of the effect of conversion of cropland to forest and grassland on GHG emissions and GWP in northeast China.

Not only is the decrease in cropland area a major driver of changes in GHG emissions, it is often the limiting factor for crop production and therefore a dominant driver of areascaled GWP. Although food demand can often be obtained with fertilizer management, the question is whether the decrease in cropland area is large enough to offset the corresponding decrease in GHG emissions, resulting in an overall lower area-scaled GWP. Furthermore, much research has focused on changes in SCS, with little on SNS. Therefore, we hypothesized that:

(i) the primary contributing factors to GWP are different among cropland, grassland, and forest

(ii) the lowest GWP is achieved with the largest changes in SCS and SNS

\section{Materials and Methods}

\section{Site Description, Climate and Management}

The study was conducted on a typical Mollisol belt in Hailun County, Heilongjiang Province, China (N47 $26^{\prime}$, E126 $\left.38^{\prime}\right)$. The mean annual temperature is $1.5^{\circ} \mathrm{C}$ and annual precipitation is $550 \mathrm{~mm}$ with $65 \%$ from June to August. The duration of the frost-free period is about 120 days. The local climate is a semi-humid temperate continental monsoon climate with long, cold winters (November to March). The winter is dry with snow cover beginning in November and snow-melt occurring in early April. The soil is classified as Pachic Haploborolls in the US system. The soil is a silty clay loam with $40 \%$ clay [25].

The studied soil was sampled from three land-use systems named as three treatments. The study location did not need specific permissions for these studies. We confirmed that the field studies did not involve endangered or protected species. The GPS coordinates of grassland, forest, and

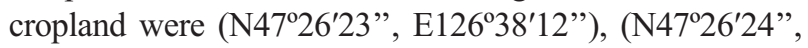
E126 $\left.38^{\prime} 59^{\prime \prime}\right)$, and (N47 $\left.26^{\prime} 14^{\prime \prime}, \mathrm{E} 126^{\circ} 38^{\prime} 12^{\prime \prime}\right)$. Before conversion, the three land-use systems had the same cropping history. They included:

i) grassland, which was converted to grassland from cropland in 1985 (total C, $33.3 \mathrm{~g} \cdot \mathrm{kg}^{-1}$; total N, $2.3 \mathrm{~g} \cdot \mathrm{kg}^{-1}$ ). Total area is $1.0 \mathrm{hm}^{2}$ of meadow steppe vegetation restoration, and the dominant species of foxtail (Leymus chinesis);

ii) forest, conversion of cropland to forest in 2000 (total C, $27.3 \mathrm{~g} \cdot \mathrm{kg}^{-1}$; total $\mathrm{N}, 1.9 \mathrm{~g} \cdot \mathrm{kg}^{-1}$ ) leading to $5.6 \mathrm{hm}^{2}$ total pine area;

iii) cropland, an experiment set up in 1985 (total C, 33.3 $\mathrm{g} \cdot \mathrm{kg}^{-1}$; total $\mathrm{N}, 2.3 \mathrm{~g} \cdot \mathrm{kg}^{-1}$ ) with a maize-soybean-wheat rotation.

The area is $60 \mathrm{~m}^{2}$, four replicates. The fertilizer application was $\mathrm{N}\left(\mathrm{kg} \cdot \mathrm{ha}^{-1}\right) 20.25$ for soybean, 112.5 for maize and wheat $\left(62.5 \mathrm{~kg} \cdot \mathrm{N} \cdot \mathrm{ha}^{-1}\right.$ as basal fertilizer at planting, and 50 $\mathrm{kg} \cdot \mathrm{N} \cdot \mathrm{ha}^{-1}$ as supplemental fertilizer in July during maize growing season); $\mathrm{P}_{2} \mathrm{O}_{5}\left(\mathrm{~kg} \cdot \mathrm{ha}^{-1}\right) 54.75$ for soybean, 45 for maize and wheat; $\mathrm{K}_{2} \mathrm{O}\left(\mathrm{kg} \cdot \mathrm{ha}^{-1}\right) 30$ for three crops, applied separately.

\section{Soil and Gas Sampling and Analysis}

The soils were sampled in October 2013 with the following procedure. Each land-use system was seen as one treatment with four replicates. In cropland, a sampling site distributed six representative points in each replicate. In grassland and forest, the sampling site located the focus of the same horizontal line as cropland and the vertical central of grassland or forest. Six destructive soil samples for each treatment were taken using a soil auger to make a composite sample from the soil profile $(0-100 \mathrm{~cm})$. Before mixing the soil sample, subsamples were used to measure soil density. One composite soil sample was made up from each 20 -cm soil profile. The composite sample was homogenized after being air-dried. The soil carbon and nitrogen content were analyzed an using ELEMENT III CHNSO analyzer (Germany). 
A static chamber technique was used for gas collection from Jan./2006 to Dec./2008. Chambers were cylindrical with a volume of $0.042 \mathrm{~m}^{3}$, surface area of $0.14 \mathrm{~m}^{2}$, and height of $0.3 \mathrm{~m}$. Each chamber was equipped with a fan to mix air and a thermocouple to record temperature in the headspace. Gas was collected at regular intervals $(0,10,20$, and $30 \mathrm{~min}$ ) from closed chambers using a syringe from 10:00 to 11:00 and was injected into $18 \mathrm{ml}$ evacuated vials. Sampling was done twice each week. Samples were analyzed using a gas chromatograph with an ECD for $\mathrm{N}_{2} \mathrm{O}$ (Shimadzu, GC2010, Japan) and with an FID for $\mathrm{CO}_{2}$ after $\mathrm{CH}_{4}$ conversion furnace (Shimadzu GC2010, Japan). Standard gases of $\mathrm{CO}_{2}$ and $\mathrm{N}_{2} \mathrm{O}$ were supplied by Haipu Corp. (Beijing, China). The rate of change in chamber concentration was calculated with linear regression.

\section{Calculation}

Gas flux

$$
\begin{aligned}
& S F_{\mathrm{CO}_{2}}=\rho_{1} \frac{d c}{d t} \times \frac{V}{A} \times \frac{273}{273+T} \times \frac{12}{44} \\
& S F_{N_{2} O}=\rho_{2} \frac{d c}{d t} \times \frac{V}{A} \times \frac{273}{273+T} \times \frac{28}{44}
\end{aligned}
$$

...where $\mathrm{SF}_{\mathrm{CO}_{2}}, \mathrm{SF}_{\mathrm{N}_{2} \mathrm{O}}$ stand for $\mathrm{CO}_{2}$ flux in $\mathrm{mg} \mathrm{C} \cdot \mathrm{m}^{-2} \cdot \mathrm{h}^{-1}$ and for $\mathrm{N}_{2} \mathrm{O}$ flux in $\mu \mathrm{g} \mathrm{N} \cdot \mathrm{m}^{-2} \cdot \mathrm{h}^{-1} ; \rho_{1}, \rho_{2}$ for $\mathrm{CO}_{2}$ and $\mathrm{N}_{2} \mathrm{O}$ density under the standard conditions, respectively; $d c / d t$ for temporal increase in $\mathrm{CO}_{2}$ and $\mathrm{N}_{2} \mathrm{O}$ concentration in the chamber headspace; $V$ for effective headspace volume of the chamber $\left(0.0168 \mathrm{~m}^{3}\right) ; A$ for the soil area covered by the chamber $\left(0.14 \mathrm{~m}^{2}\right)$; and $T$ for air temperature inside the chamber.

Soil C and N stock were calculated as follows:

$$
\mathrm{SCS}=\mathrm{BD} \times \mathrm{SC} \times \mathrm{D}, \mathrm{SNS}=\mathrm{BD} \times \mathrm{ST} \times \mathrm{D}
$$

...where SCS and SNS $\left(\mathrm{g} \cdot \mathrm{cm}^{-2}\right)$ are the soil C and N stock; $\mathrm{BD}\left(\mathrm{g} \cdot \mathrm{cm}^{-3}\right)$ is soil bulk density; $\mathrm{SC}$ and $\mathrm{SN}\left(\mathrm{g} \cdot \mathrm{kg}^{-1}\right)$ are the concentration of SOC content and total $\mathrm{N}$ content; D $(\mathrm{cm})$ is soil depth.

\section{GWP Calculation}

$$
\begin{aligned}
& \mathrm{GWP}=\mathrm{GWP}_{\text {fertilizer }}+\mathrm{GWP}_{\text {pesticides }}+\mathrm{GWP}_{\text {agriculture machinery }}+ \\
& \mathrm{GWP}_{\text {seed production }}+\mathrm{GWP}_{\Delta \mathrm{SOC}}+\mathrm{GWP}_{\mathrm{N}_{2} \mathrm{O}}
\end{aligned}
$$

There are only 3-year $\mathrm{N}_{2} \mathrm{O}$ and $\mathrm{CO}_{2}$ emission data. The mean 3-year data was used to estimate the long-term $\mathrm{GWP}_{\mathrm{N}_{2} \mathrm{O} \text { and } \mathrm{CO}_{2}} \cdot \mathrm{GWP}_{\text {fertilizer, agriculture machinery and seed production were }}$ based on the $\mathrm{C}$ equivalents referred to by West and Marland [26].

$$
\begin{gathered}
\mathrm{GWP}_{\triangle \mathrm{SOC}}=\mathrm{SOC}_{1985}-\mathrm{SOC}_{2013} \text { for cropland and grassland, } \\
\mathrm{GWP}_{\Delta \mathrm{SOC}}=\mathrm{SOC}_{2000}-\mathrm{SOC}_{2013} \text { for forest } \\
\mathrm{GWP}_{\mathrm{N}_{2} \mathrm{O}}=298 \times \mathrm{N}_{2} \mathrm{O} \times 12 / 44
\end{gathered}
$$

\section{Statistical Analyses}

The differences in change of SCS (soil carbon stock), SNS (soil nitrogen stock), gas fluxes, and GWP across cropland, grassland, and forest were tested with statistical procedure of Origin 8 software at a significance level of 0.05. Correlations between GWP and $\triangle \mathrm{TSC}$ (total soil carbon change), $\triangle \mathrm{TSN}$ (total soil nitrogen change), $\mathrm{CO}_{2}$, and $\mathrm{N}_{2} \mathrm{O}$ emissions were analyzed using Excel 2010 software.

\section{Results}

\section{Soil Bulk Density, Water Content, and Cand N Content}

Mean data for soil density, water content, soil C and N content, determined in the soil from different depths taken from cropland, grassland, and forest land, are given in Table 1. Bulk density and water content generally decreased upon conversion from agricultural land to grassland or forest at the same depth, when compared to cropland. The average decrease in bulk density following conversion to grassland was $3.8 \%(n=5)$ and that of forest $1.6 \%(n=4)$ without 60 $80 \mathrm{~cm}$. The average water content was decreased by $24.1 \%$ and $15.4 \%$ upon conversion of agricultural land to grassland and forest, respectively. The total soil $\mathrm{C}$ and $\mathrm{N}$ in grassland increased by $51.1 \%$ and $28.4 \%$ at 28 y after conversion, and decreased by $7.2 \%$ and $5.2 \%$ at $14 \mathrm{y}$ following conversion to forest. The depth to which soil samples are taken can significantly influence estimates of soil bulk density, water content, and total $\mathrm{C}$ and $\mathrm{N}$ contents. All these data decreased with soil depth.

\section{$\mathrm{CO}_{2}$ and $\mathrm{N}_{2} \mathrm{O}$ Emissions}

Soil $\mathrm{CO}_{2}$ fluxes integrated over time was similar in all three land-use systems (Fig. 1). The $\mathrm{CO}_{2}$ flux rates were low in January/February, but increased throughout May to September in conjunction with plant growth and a higher growing season temperature. The average $\mathrm{CO}_{2}$ flux from 2006 to 2008 was $39.8,46.7$, and $40.9 \mathrm{mg} \mathrm{CO}-\mathrm{C} \cdot \mathrm{m}^{-2} \cdot \mathrm{h}^{-1}$ in cropland, grassland, and forest. The cumulative soil $\mathrm{CO}_{2}$ emission per year was highest in grassland $\left(4033 \mathrm{mg} \mathrm{CO}_{2}\right.$ $\mathrm{C} \cdot \mathrm{ha}^{-1}$ ), followed by forest ( $\left.3537 \mathrm{mg} \mathrm{CO}_{2}-\mathrm{C} \cdot \mathrm{ha}^{-1}\right)$, and cropland (3443 $\mathrm{mg} \mathrm{CO}_{2}-\mathrm{C} \cdot \mathrm{ha}^{-1}$ ).

The average $\mathrm{N}_{2} \mathrm{O}$ fluxes in cropland, grassland, and forest were 5.5, 7.9, and $1.3 \mu \mathrm{g} \mathrm{N}_{2} \mathrm{O}-\mathrm{N} \cdot \mathrm{m}^{-2} \cdot \mathrm{h}^{-1}$. There were some extreme peaks in cropland (July/August, 2006, May, 2007), but $\mathrm{N}_{2} \mathrm{O}$ flux on other dates was even lower in cropland than grassland. Forest land in general had the lowest $\mathrm{N}_{2} \mathrm{O}$ flux during the three years measured (Fig. 1).

\section{Changes in Total Soil C and N}

For each of the three categories of land use considered (cropland, grassland, and forest), land use significantly affected the change in total soil C stock (TSC) and N stock 
Table 1. Soil bulk density, water content, and total $\mathrm{C}$ and $\mathrm{N}$ from three soil plots, respectively.

\begin{tabular}{|c|c|c|c|c|c|}
\hline Land use & Depth $(\mathrm{cm})$ & Bulk density $\left(\mathrm{g} \cdot \mathrm{cm}^{-3}\right)$ & Water content $(\%)$ & $\mathrm{C}\left(\mathrm{g} \cdot \mathrm{kg}^{-1}\right)$ & $\mathrm{N}\left(\mathrm{g} \cdot \mathrm{kg}^{-1}\right)$ \\
\hline \multirow{5}{*}{ Cropland } & $0-20$ & $1.09 \pm 0.00$ & $28.40 \pm 0.30$ & $34.15 \pm 0.76$ & $2.45 \pm 0.05$ \\
\cline { 2 - 6 } & $20-40$ & $1.23 \pm 0.04$ & $31.54 \pm 1.01$ & $23.84 \pm 1.62$ & $1.52 \pm 0.14$ \\
\cline { 2 - 6 } & $40-60$ & $1.30 \pm 0.01$ & $29.48 \pm 0.30$ & $15.73 \pm 0.34$ & $0.82 \pm 0.07$ \\
\cline { 2 - 6 } & $60-80$ & $1.30 \pm 0.03$ & $28.04 \pm 0.21$ & $11.97 \pm 0.23$ & $0.67 \pm 0.07$ \\
\hline \multirow{5}{*}{ Grassland } & $80-100$ & $1.35 \pm 0.01$ & $27.94 \pm .027$ & $10.52 \pm 0.24$ & $0.55 \pm 0.00$ \\
\cline { 2 - 6 } & $0-20$ & $0.98 \pm 0.04$ & $17.91 \pm 0.27$ & $43.46 \pm 0.67$ & $3.48 \pm 0.02$ \\
\cline { 2 - 6 } & $20-40$ & $1.22 \pm 0.02$ & $25.41 \pm 0.27$ & $33.46 \pm 0.58$ & $2.55 \pm 0.09$ \\
\cline { 2 - 6 } & $40-60$ & $1.26 \pm 0.03$ & $25.85 \pm 0.36$ & $21.87 \pm 0.07$ & $1.53 \pm 0.05$ \\
\hline \multirow{5}{*}{ Forest } & $60-80$ & $1.24 \pm 0.03$ & $27.37 \pm 0.26$ & $14.65 \pm 0.71$ & $0.91 \pm 0.10$ \\
\cline { 2 - 6 } & $80-100$ & $1.36 \pm 0.01$ & $26.40 \pm 0.21$ & $10.09 \pm 0.75$ & $0.61 \pm 0.07$ \\
\cline { 2 - 6 } & $0-20$ & $1.11 \pm 0.02$ & $17.08 \pm 0.51$ & $29.50 \pm 1.13$ & $2.10 \pm 0.10$ \\
\hline & $20-40$ & $1.22 \pm 0.06$ & $22.69 \pm 0.45$ & $23.67 \pm 0.44$ & $1.51 \pm 0.04$ \\
\hline
\end{tabular}

(TSN) to $100 \mathrm{~cm}$ (Fig. 2). On average, the changes in TSC of the entire $100 \mathrm{~cm}$ profile were $-523,1722$, and $-239 \mathrm{~kg} \cdot \mathrm{ha}^{-1} \cdot \mathrm{y}^{-1}$ in cropland, grassland, and forest, TSN being $-83,170$, and $-46 \mathrm{~kg} \cdot \mathrm{ha}^{-1} \cdot \mathrm{y}^{-1}$, respectively.

There was a significant increase in change of soil $\mathrm{C}$ stock (SCS) and soil N stock (SNS) in the upper $20 \mathrm{~cm}$ of the soil profile after 28 y cultivation in cropland (Fig. 3 ). However, changes in SCS and SNS tended to decrease marginally in the 20-100 cm layer. The deeper the sampling depth, the smaller the change in SCS and SNS. After the conversion from agricultural land to grassland, the changes in SCS and SNS were larger than those in cropland and for- est (with the exception of the 40-60 $\mathrm{cm}$ layer), and showed a significant positive increase (Fig. 3). However, the changes in SCS and SNS were nevertheless larger in forest compared to unchanged cropland.

\section{Global Warming Potential (GWP)}

The GWP of the cropland ( $717 \mathrm{~kg} \mathrm{CO}_{2}-\mathrm{C}$ equivalents $\mathrm{ha}^{-1} \cdot \mathrm{y}^{-1}$ ) was significantly the highest, followed by the forest and grassland at -324 and $-1667 \mathrm{~kg} \mathrm{CO}_{2}-\mathrm{C}$ equivalents $\mathrm{ha}^{-1} \cdot \mathrm{y}^{-1}$, respectively (Table 2 ). The main difference in GWP across land use was attributable to differences in changes in
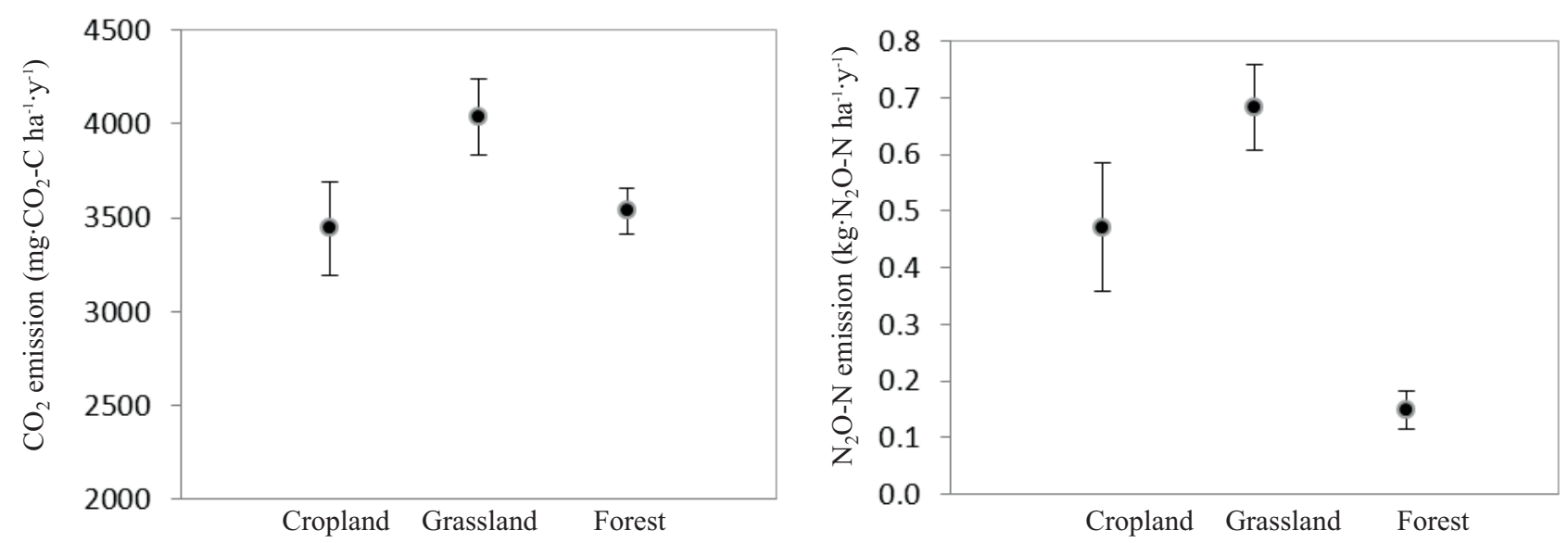

Fig. 1. Soil $\mathrm{CO}_{2}$ and $\mathrm{N}_{2} \mathrm{O}$ emissions from cropland, converted to grassland for 29 years and forest for 14 years. Bars are \pm standard deviation. 
Table 2. Estimated net global warming potential (GWP) ( $\mathrm{kg} \mathrm{CO}_{2}$-C equivalents $\left.\mathrm{ha}^{-1} \cdot \mathrm{yr}^{-1}\right)$.

\begin{tabular}{|l|c|c|c|}
\hline \multicolumn{4}{|c|}{ Agricultural production ${ }^{\mathrm{a}}$} \\
\hline GWP components & NPK & GL & PL \\
\hline N fertilizer & 68 & - & - \\
\hline P fertilizer & 7 & - & - \\
\hline K fertilizer & 14 & - & - \\
\hline Seed & 20 & - & - \\
\hline Pesticides & 15 & - & - \\
\hline Machinery & 69 & - & - \\
\hline Total & 194 & - & - \\
\hline Pine fix $C^{\text {b }}$ & - & - & -575 \\
\hline$\triangle$ Soil C $^{\mathrm{c}}$ & $523 \pm 197$ & $-1722 \pm 176$ & $239 \pm 98$ \\
\hline Soil N$_{2} \mathrm{O}^{\mathrm{d}}$ & $38 \pm 6$ & $55 \pm 3$ & $12 \pm 1$ \\
\hline GWP $^{\mathrm{e}}$ & $755 \pm 192 \mathrm{a}$ & $-1667 \pm 175 \mathrm{c}$ & $-324 \pm 99 \mathrm{~b}$ \\
\hline
\end{tabular}

${ }^{\mathrm{a}}$ Carbon cost associated with crop production

${ }^{\mathrm{b}} \mathrm{C}$ fixed by pine biomass

${ }^{\mathrm{c}} \triangle$ Soil C $=\mathrm{SOC}_{1985}-\mathrm{SOC}_{2013}$ for cropland and grassland;

$\triangle$ Soil C $=\mathrm{SOC}_{2000}-\mathrm{SOC}_{2013}$ for forest

${ }^{\mathrm{d}} \mathrm{GWP}\left(\mathrm{kg} \mathrm{CO}_{2}-\mathrm{C}\right.$ equivalents ha $\left.{ }^{-1} \cdot \mathrm{yr}^{-1}\right)=298 \times \mathrm{N}_{2} \mathrm{O} \times 12 / 28$

${ }^{\mathrm{e}} \mathrm{GWP}=$ agricultural production + Pine fix $\mathrm{C}+\Delta$ Soil $\mathrm{C}+\mathrm{N}_{2} \mathrm{O}$

$\mathrm{a}, \mathrm{b}$, and $\mathrm{c}$ mean statistically siginificant at $\mathrm{p}<0.05$.

SOC ( $\triangle \mathrm{SOC})$, agricultural production, $\mathrm{N}_{2} \mathrm{O}$ emission, and pine fixed-C. The $\triangle$ SOC contributed $69 \%,-100 \%$, and $74 \%$ of GWP in cropland, grassland, and forest system, respectively. $\mathrm{N}_{2} \mathrm{O}$ emissions accounted for $5 \%,-3 \%$, and $-4 \%$, correspondingly.

The correlation analysis between gas emission, changes in TSC, TSN, and GWP is shown in Fig. 4. There was a significant positive relationship between change in $\mathrm{CO}_{2}$ and $\operatorname{GWP}\left(\mathrm{R}^{2}=0.7835\right.$; significant at $1 \%$ significance level $)$, and between change in $\mathrm{N}_{2} \mathrm{O}$ and GWP $\left(\mathrm{R}^{2}=0.5496\right.$; significant at $5 \%$ significance level). No significant relationship was found between soil total C and N stock (TSC and TSN) and GWP.

\section{Discussion}

\section{$\mathrm{C}$ and $\mathrm{N}$ Changes Following Conversion from Agricultural Land to Grassland}

Following conversion of cropland to grassland for $28 \mathrm{y}$, soil $\mathrm{C}$ and $\mathrm{N}$ content increased significantly (Table 1). This is because that grassland contains a large aboveground biomass of 1-3 $\mathrm{t} \cdot \mathrm{C} \cdot \mathrm{ha}^{-1}$ and a higher root and shoot ratio compared to cropland [27]. Thus, a greater proportion of the root organic $\mathrm{C}$ was retained in soil and large amounts of above-ground litter returned to soil without annual removal through harvest. Moreover, the new material input is easy to decompose and therefore stimulates the $\mathrm{C}$ cycle in grassland system [28]. In our study, the highest emission of $\mathrm{CO}_{2}$ and $\mathrm{N}_{2} \mathrm{O}$ occurred in grassland and represented an increase of $17 \%$ and $40 \%$ compared to cropland (Fig. 1). Grass develops extensive root systems [10] and a C input of $3.15 \mathrm{t} \cdot \mathrm{C} \cdot \mathrm{ha}^{-1}$ (about 12 times to cropland) contributed to SOC accumulation. The present results show that the average rates of soil $\mathrm{C}$ stock ranged from 87 to $711 \mathrm{~kg} \cdot \mathrm{C} \cdot \mathrm{ha}^{-1} \cdot \mathrm{y}^{-1}$ throughout the soil profile $(0$ $80 \mathrm{~cm}$ ). Our results were in accordance with a maximum SOC accumulation rate of $1100 \mathrm{~kg} \cdot \mathrm{C} \cdot \mathrm{ha}^{-1} \cdot \mathrm{y}^{-1}$, previously observed in the surface $300 \mathrm{~cm}$ [29]. Soil sampling depth influenced the magnitude of change in soil C stocks after conversion from cropland to grassland. The deeper the sampling depth, the less effect of the grass on soil $\mathrm{C}$ stocks [8]. These data showed that grass could cause substantial $\mathrm{C}$ accumulation up to $80 \mathrm{~cm}$ depth, but this contribution decreased by $100 \mathrm{~cm}$ layer. Moreover, the change in soil $\mathrm{N}$ stock showed the same trend as $\mathrm{C}$ stock after conversion from agricultural land to grassland.
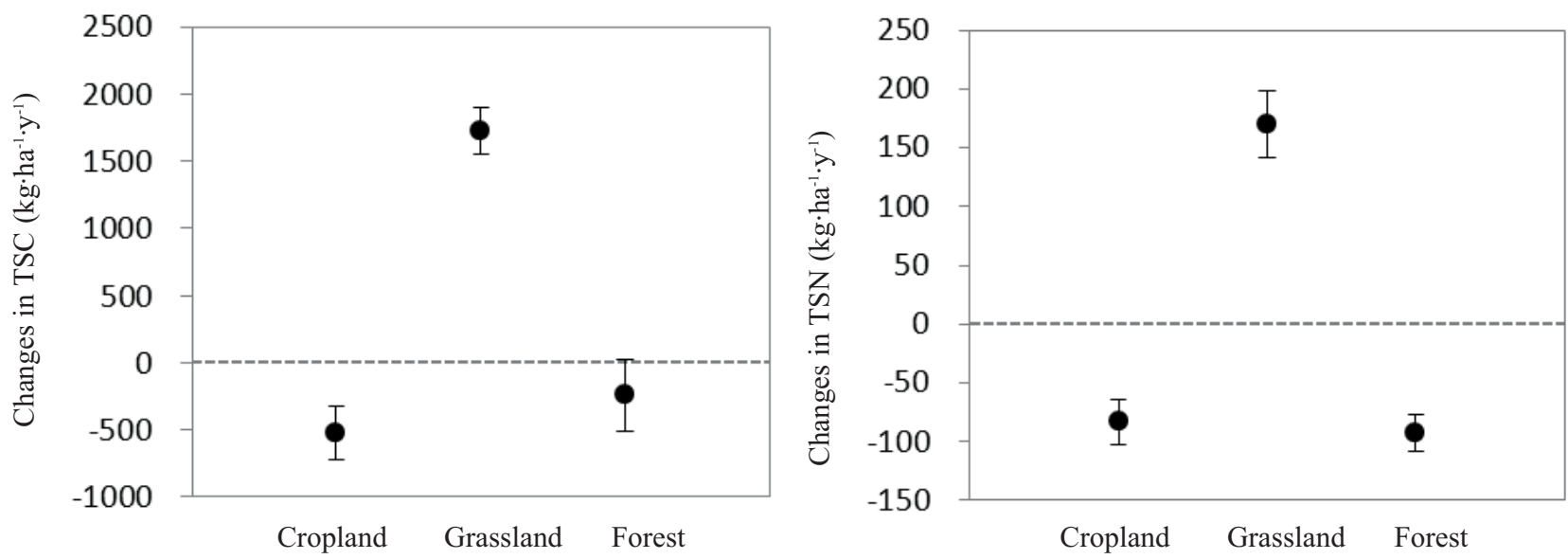

Fig. 2. Influence of conversion from cropland to grassland (28 y) and forest (14 y) on changes in TSC and TSN at $100 \mathrm{~cm}$ layer. The error bars are the standard errors of the mean. 


\section{$\mathrm{C}$ and N Changes Following Conversion from Agricultural Land to Forest}

The results of the present study showed that afforestation of cropland did not lead to increased $\mathrm{C}$ and $\mathrm{N}$ content in the soil over $14 \mathrm{y}$ in the full $100 \mathrm{~cm}$ profile (Table 1). This is in agreement with several studies in boreal zones after conversion from agricultural land to forest, as discussed in the review by Laganiere et al. [19]. Conversion from cropland to forest implies that the annual cycle of cultivating and harvesting crops is replaced by the much longer forest cycle. In the forest system, the balance of $\mathrm{C}$ and $\mathrm{N}$ input and output of the cropland system is broken [19]. The lower soil $\mathrm{C}$ and $\mathrm{N}$ input occurs due to a smaller forest biomass and low rate of litterfall $[19,30]$. In addition, the slower decomposition rate in the boreal zone is a major factor inhibiting $\mathrm{C}$ and $\mathrm{N}$ input [31]. Hence, the present result is supported by previous observations in which soil carbon initially decreased during the first $12 \mathrm{y}$ before gradual recovery and accumulation of soil carbon occurred [24].

In the present study, $\mathrm{CO}_{2}$ emission per year in forest (3.5 $\mathrm{g} \mathrm{CO}_{2}-\mathrm{C} \mathrm{ha}{ }^{-1} \cdot \mathrm{y}^{-1}$ ) was comparable to cropland (3.4 $\mathrm{g} \mathrm{CO}_{2}-\mathrm{C} \mathrm{ha}^{-1} \cdot \mathrm{y}^{-1}$, Fig. 1). The $\mathrm{CO}_{2}$ emission measurement included root respiration and soil respiration. The relative large pine root biomass contributes more $\mathrm{CO}_{2}$ respired [32]. The return of $\mathrm{C}$ was larger from pine $\left(1.36 \mathrm{t} \cdot \mathrm{ha}^{-1}\right)$ than cropland $\left(0.27 \mathrm{t} \cdot \mathrm{ha}^{-1}\right)$ (data not shown). All of the above favor the emission of $\mathrm{CO}_{2}$ in the forest. Furthermore, the conversion of cropland to forest modifies the quality and quantity of litter inputs and soil microbial and faunal communities $[19,33]$. In contrast, $\mathrm{N}_{2} \mathrm{O}$ emissions per year were lower in forest $\left(0.1 \mathrm{~kg} \mathrm{~N}_{2} \mathrm{O}-\mathrm{N} \cdot \mathrm{ha}^{-1}\right)$ than cropland $\left(0.5 \mathrm{~kg} \mathrm{~N}_{2} \mathrm{O}-\mathrm{N} \cdot \mathrm{ha}^{-1}\right)$ in our study. As we know, $\mathrm{N}_{2} \mathrm{O}$ emissions are mainly associated with nitrogen turnover in natural soil. Human activities intensify the process through $\mathrm{N}$ fertilizer application
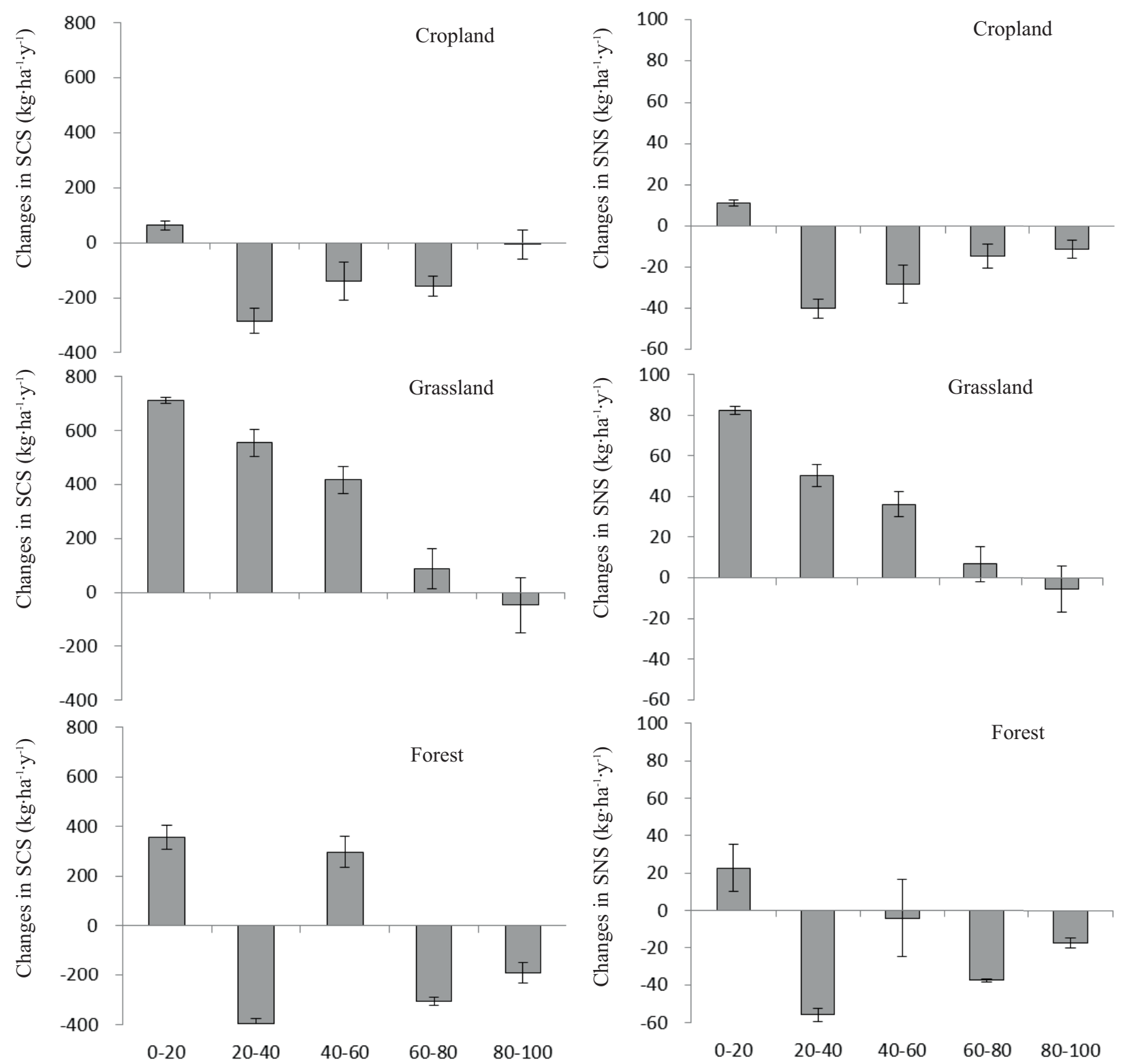

Fig. 3. Influence of conversion from cropland to grassland (28 y) and forest (14 y) on changes in SCS and SNS at different depth layer. The error bars are the standard errors of the mean. 
and soil management $[2,34]$. After conversion of cropland to forest, there was little human activity to provoke $\mathrm{N}_{2} \mathrm{O}$ emissions. At the same time, our results were within the value reported by Ullah et al. [35], who researched $\mathrm{N}_{2} \mathrm{O}$ emissions in three forest types in eastern Canada.

Over a 14-year conversion from cropland to forest, there was no significant difference in soil $\mathrm{C}$ and $\mathrm{N}$ contents compared to cropland. However, the change in SCS and SNS of the entire $100 \mathrm{~cm}$ layer was less in forest (54\%) compared to cropland (Fig. 2). This is due, first of all, to the high NPP of pine, which increases C inputs to soil [36]. Second, the lack of tillage operations reduce disturbance and provide better protection of soil organic carbon against decomposition [37]. Third, the recalcitrance of C inputs is greater in forest than cropland [38]. All these reasons contributed to the observed change. Furthermore, the deeper root system in pine induced a change in SCS in the 80-100 $\mathrm{cm}$ layer, not seen in cropland.

\section{GWP after Conversion from Cropland to Grassland and Forest}

Agricultural production, $\triangle \mathrm{SOC}, \mathrm{N}_{2} \mathrm{O}$ emission, and pine $\mathrm{C}$ fixed as biomass were used to estimate the GWP in each of the three land use systems (Table 2). In northeast China rain-fed agricultural systems, the $\mathrm{CH}_{4}$ emissions are very low at $<2 \mathrm{~g} \cdot \mathrm{ha}^{-1}$ [39]; $\mathrm{CH}_{4}$ emission was therefore not considered in this study. However, the energy used for farming operations such as fertilizer production, seed, pesticides, and machinery was included as indicated in reports of Qiao et al. [34] and Thelen et al. [40]. $\triangle \mathrm{SOC}$ was calculated as the change in C between 1985 and 2013 for cropland and grassland, and between 2000 and 2013 for forest.

The results in this study show that $\triangle \mathrm{SOC}$ was the dominant contributor to the GWP across three systems. In the $100 \mathrm{~cm}$ soil profile, $\mathrm{C}$ generally increased following conversion from agricultural land to grassland and forest, which is consistent with changes observed for surface soils following afforestation in northeast China [24] and permanent grassland conversion [41]. However, the present results showed that GWP was positively related to $\mathrm{CO}_{2}$ and $\mathrm{N}_{2} \mathrm{O}$ emissions, but not to $\triangle \mathrm{TSC}$ and $\triangle \mathrm{TSN}$ (Fig. 4). These data affirm that changing $\mathrm{CO}_{2}$ and $\mathrm{N}_{2} \mathrm{O}$ emissions through conversion of cropland to grassland and forest is a major consideration toward mitigating GWP in these soils.
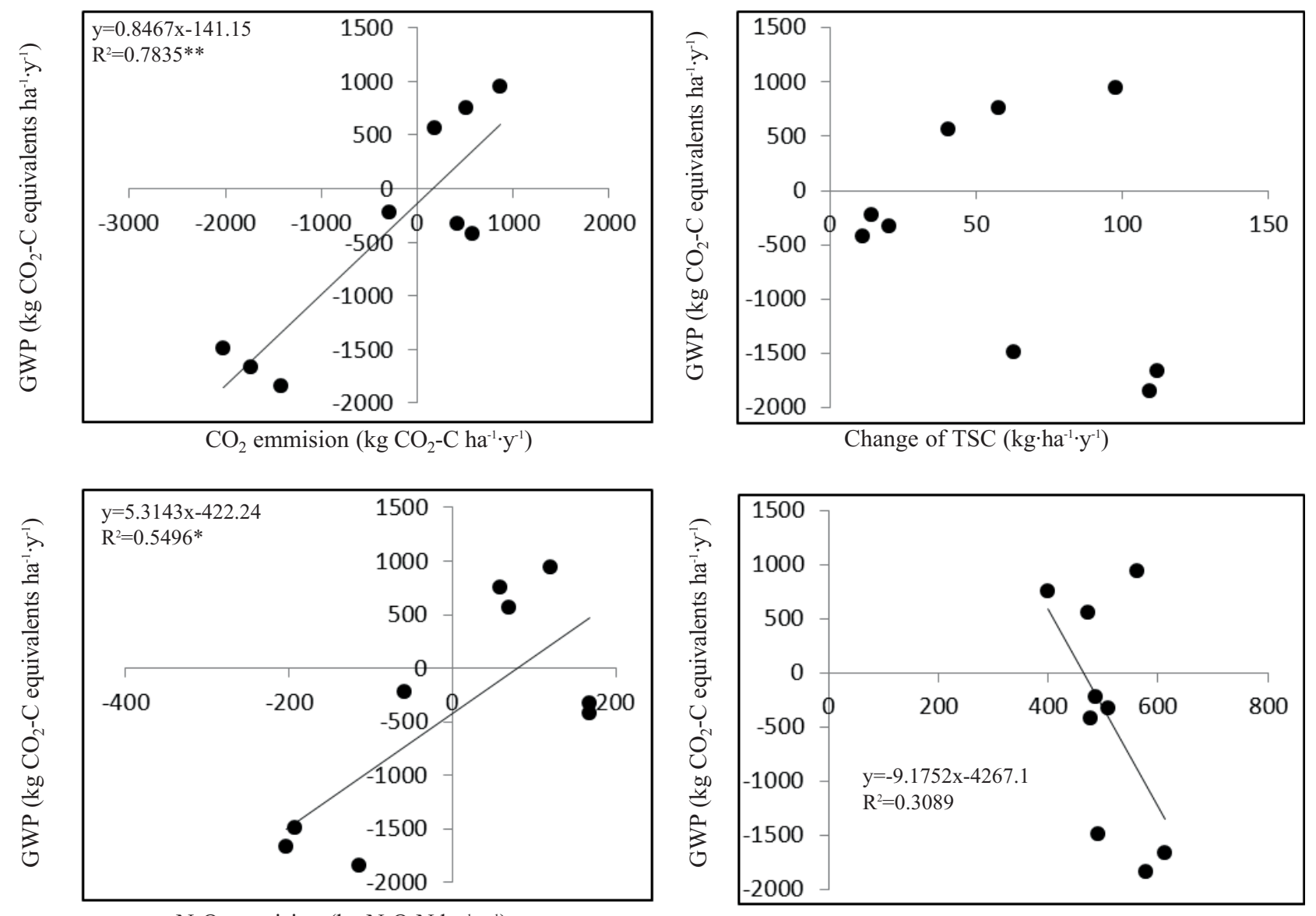

$\mathrm{N}_{2} \mathrm{O}$ emmision $\left(\mathrm{kg} \mathrm{N}_{2} \mathrm{O}-\mathrm{N}\right.$ ha $\left.^{-1} \cdot \mathrm{y}^{-1}\right)$

Change of TSN $\left(\mathrm{kg} \cdot \mathrm{ha}^{-1} \cdot \mathrm{y}^{-1}\right)$

Fig. 4. The relationship between GWP and $\mathrm{CO}_{2}, \mathrm{~N}_{2} \mathrm{O}$, changes in TSC and TSN after conversion from cropland to grassland (28 y) and forest (14 y). 


\section{Acknowledgements}

The authors wish to express thanks to Profesor Xiaobing Liu and Timothy A. Doane for invaluable comments. This work was funded by the National Natural Science Foundation of China (41371297) and Nanjing University of Information Science \& Technology Telent Start-up Fund.

\section{References}

1. BARRETT C.B. Measuring Food Insecurity. Science 327, 825, 2010.

2. KIRSCHBAUM M.U.F., SAGGAR S., TATE K.R., GILTRAP D.L., AUSSEIL A.G.E. Comprehensive evaluation of the climate-change implications of shifting land use between forest and grassland: New Zealand as a case study. Agr. Ecosyst. Environ. 150, 123, 2012.

3. SOLOMON S., QIN D., MANNING M., CHEN Z., MARQUIS M., AVERYT K.B., TIGNOR M., MILLER H. L. IPCC. Summary for policy makers. In: the TPSBCoWGIt, Climate FARotIPo, Change, editors. Climate Change ed. Cambridge University Press, Cambridge, United Kingdom and New York. pp. 1-18, 2007.

4. JOBBÁGY E.G., JACKSON R.B. The vertical distribution of soil organic carbon and its relation to climate and vegetation. Ecol. Appl. 10, 423, 2000.

5. SHI S., ZHANG W., ZHANG P., YU Y., DING F. A synthesis of change in deep soil organic carbon stores with afforestation of agricultural soils. Forest Ecol. Manag. 296, 53, 2013.

6. MCKINLEY D.C., RYAN M.G., BIRDSEY R.A., GIARDINA C.P., HARMON M.E. A synthesis of current knowledge on forests and carbon storage in the United States. Ecol. Appl. 21, 1902, 2011.

7. POST W.M., KWON K.C. Soil carbon sequestration and land-use change: processes and potential. Global Change Biol. 6, 317, 2000.

8. GUO L.B., GIFFORD R.M. Soil carbon stocks and land use change: a meta analysis. Global Change Biol. 8, 345, 2002.

9. VESTERDAL L., RITTER E., GUNDERSEN P. Change in soil organic carbon following afforestation of former arable land. Forest Ecol. Manag. 169, 137, 2002.

10. ZHANG K., DANG H., TAN S., CHENG X., ZHANG Q. Change in soil organic carbon following the 'Grain-forGreen' programme in China. Land Degrad. Dev. 21, 13, 2010.

11. SMITH P. Land use change and soil organic carbon dynamics. Nutr. Cycli. Agroecosystems. 81, 169, 2008.

12. ARORA V.K., BOER G.J. Uncertainties in the 20th century carbon budget associated with land use change. Global Change Biol. 16, 3327, 2010.

13. FORSTER P., RAMASWAMY V., ARTAXO P., BERNTSEN T., BETTS R. Changes in atmospheric constituents and in radiative forcing. Cambridge, United Kingdom: Cambridge University Press. pp. 129-234, 2007.

14. SAGGAR S., TATE K.R., GILTRAP D.L., SINGH J. Soilatmosphere exchange of nitrous oxide and methane in New Zealand terrestrial ecosystems and their mitigation options: a review. Plant Soil 309, 25, 2008.

15. SMITH P., MARTINO D., CAI Z., GWARY D., JANZEN H. Greenhouse gas mitigation in agriculture. Phil. Trans. R. Soc. B. 363, 789, 2008.
16. SMITH P., MARTINO D., CAI Z.C., GWARY D., JANZEN H. Policy and technological constraints to implementation of greenhouse gas mitigation options in agriculture. Agr. Ecosyst. Environ. 118, 6, 2007.

17. KELLIHER F.M., CLARK H., LI Z., NEWTON P.C.D., PARSONS A.J. A comment on scaling methane emissions from vegetation and grazing ruminants in New Zealand. Funct. Plant Biol. 33, 613, 2006.

18. KIRSCHBAUM M.U.F., BRUHN D., ETHERIDGE D.M., EVANS J.R., FARQUHAR G.D. A comment on the quantitative significance of aerobic methane release by plants. Funct. Plant Biol. 33, 521, 2006.

19. LAGANIERE J., ANGERS D.A., PARE D. Carbon accumulation in agricultural soils after afforestation: a metaanalysis. Global Change Biol. 16, 439, 2010.

20. IPCC. Third Assessment Report. Climate Change 2001: Cambridge University Press, pp. 231, 2001.

21. MEKI M.N., KEMANIAN A.R., POTTER S.R., BLUMENTHAL J.M., WILLIAMS J.R. Cropping system effects on sorghum grain yield, soil organic carbon, and global warming potential in central and south Texas. Agri. Systems 117, 19, 2013.

22. PAUSTIAN K.E., ELLIOTT T., KILLIAN K., CIPRA J., BLUHM G. Modeling and regional assessment of soil carbon: a case study of the Conservation Reserve Program.; Lal R MK, editor. Madison, WI: SSSA Special Publ. pp. 315318, 2001.

23. FAO. Food and Agriculture Organization. Access at WWW. fao.org. 2010.

24. WANG C.M., OUYANG H., SHAO B., TIAN Y.Q., ZHAO J.G. Soil Carbon Changes Following Afforestation with Olga Bay Larch (Larix olgensis Henry) in Northeastern China. J. Integr. Plant Biol. 48, 503, 2006.

25. XING B.S., LIU X.B., LIU J.D., HAN X.Z. Physical and chemical characteristics of a typical Mollisol in China. Commun. Soil Sci. Plan. 35, 1829, 2004.

26. WEST T.O., MARLAND G. A synthesis of carbon sequestration, carbon emissions, and net carbon flux in agriculture: comparing tillage practices in the United States. Agr. Ecosyst. Environ. 91, 217, 2002.

27. VERCHOT L., KRUG T., LASCO R.D., OGLE S., YUE L.Y. Chapter 6, Grassland, pp. 256, 2006.

28. SHANG Z. H., CAO J. H., GUO R. Y., LONG R. J., DENG B. The response of soil organic carbon and nitrogen 10 years after returning cultivated alpine steppe to grassland by abandonment or reseeding. Catena. 119, 28, 2014.

29. GEBHART D.L., JOHNSON H.B., MAYEUX H.S., POLLEY H.W. The CRP increases in soil organic carbon. J. Soil Water Conserv. 49, 488, 1994

30. WANG C.M. Impact of converting cropland to forest on the carbon balance and cost-benefit assessment. Beijing: Chinese Academy of Science, pp. 136-138, 2005.

31. VAVTVA P., PENTTILË T., LAIHO R. Decomposition of Scots pine fine woody decris in boreal conditions: Implications for estimating carbon pools and fluxes. Forest Ecol. Manag.. 257, 401, 2009.

32. ORAL H. V., GUNEY M., KUCUKER M. A., ONAY T. T., COPTY N. K., MATER B., YENIGUN O. The impact of hazelnuts in land-use changes on soil carbon and in situ soil respiration dynamics. J. Environ. Manag. 129, 341, 2013.

33. BOUWMAN A.F., LEEMANS R. The role of forest soils in the global carbon cycle. Soil Science Society of America, Madison, WI. pp. 431, 1995. 
34. QIAO Y.F., MIAO S.J., HAN X.Z., YOU M.Y., ZHU X The effect of fertilizer practices on $\mathrm{N}$ balance and global warming potential of maize-soybean-wheat rotations in Northeastern China. Field Crops Research, 161, 98, 2014.

35. ULLAH S., FRASIER R., KING L., PICOTTE-ANDERSON N., MOORE T. R. Potential fluxes of $\mathrm{N}_{2} \mathrm{O}$ and $\mathrm{CH}_{4}$ from soils of three forest types in Eastern Canada. Soil Biol. Biochem. 40, 986, 2008.

36. IMHOFF M.L., BOUNOUA L., RICKETTS T., LOUCKS C., HARRISS R. Global patterns in human consumption of net primary production. Nature 429, 870, 2004.

37. SIX J., ELLIOTT E.T., PAUSTIAN K. Soil macroaggregate turnover and microaggregate formation: a mechanism for $\mathrm{C}$ sequestration under no-tillage agriculture. Soil Biol. Biochem. 32, 2099, 2000.
38. CERLI C., CELI L., JOHANSSON M.B., KOGELKNABNER I., ROSENQVIST L. Soil organic matter changes in a spruce chronosequence on Swedish former agricultural soil I. Carbon and lignin dynamics. Soil Sci. 171, 837, 2006.

39. DING W.X., WANG Y., WANG D. Emission of $\mathrm{CO}_{2}$ and $\mathrm{CH}_{4}$ from black soil in northeast china. J. Agro-Environ. Sci. 22, 720, 2003.

40. THELEN K.D., FRONNING B.E., KRAVCHENKO A., MIN D.H., ROBERTSON G.P. Integrating livestock manure with a corn-soybean bioenergy cropping system improves short-term carbon sequestration rates and net global warming potential. Biomass Bioenerg. 34, 960, 2010.

41. FISHER M.J., RAO I.M., AYARZA M.A. Carbon storage by introduced deep-rooted grasses in South American savannas. Science 371, 236, 1994. 
